reference has already been made in Nature (see NATURE of March 4, p. 386). The report is fully illustrated and accompanied by plans. Mr. James Hornell draws on his world-wide knowledge of the construction of various forms of boat to trace the plank-built boat to its origin. Among the interesting shorter notes which are always a feature of the contents, mention should be made on this occasion of a valuable suggestion from Mr. Stanley Casson, urging the prosecution of submarine research in the coastal waters of Greece. He points out that not only are the sea routes of antiquity well known, but recent discoveries of statuary, especially bronzes of the best period of classical art, support the argument that cargoes of artistic loot on the way to Rome may have been lost with some frequency.

\section{Design of Electric Power Stations}

AN important paper by F. W. Lawton was read to the Institution of Electrical Engineers on March 9 dealing with the design of Hams Hall power station at Birmingham, designed twelve years ago, and with a new Hams Hall power station $B$ which will be constructed shortly for the same purpose and on a neighbouring site. The author stresses the point that from the time when the calculations for a proposed power station are made until it is completed and running on a commercial load, several years may have elapsed and great changes may have occurred. For example, the average price of the coal used in the furnaces is now $17 s$. per ton as against $9 s .6 d$. in 1935 . In designing the new station it was reasonable to consider which features of the old station should be repeated and which rejected in the new station built twelve years afterwards. During this time coal prices have increased, high voltages have become normal and the progress made in metallurgy has made much higher steam temperatures feasible. All these changes call for modification in the designs if the best efficiency and economy are to be obtained. As regards the general lay-out, the simplicity and uniformity of the existing station will be repeated. There is a single row of boilers parallel to a single end-on row of turbo alternators. Electrostatic flue-gas cleaning plant will be retained. The absence of architectural adornment of the new buildings will be more rigorously enforced. Air raid precautions insist that there must be no roof lights or external windows to basements. For economic reasons the superstructure will be made of ferro-concrete instead of structural steel. Turboalternators of $50,000 \mathrm{kw}$. capacity each will again be used in the new station, but they will generate at 33,000 volts instead of at 11,000 volts as in the present station. A true understanding of what is real economy is obscured by the ever-changing technology of power production, by the difficulties of accurately forecasting operating conditions many years ahead, and by reactions of local trade developments.

\section{Research at the Kodak Laboratories}

ThiRTX-NINe papers are covered in the recently published "Abridged Scientific Publications from Kodak Research Laboratories" (vol. 19. Pp. viii +
288. Rochester, New York : Eastman Kodak Co.). The wide variety of subjects studied at the Kodak Laboratories is well illustrated. Most of the papers have some obvious connexion with photographic manufacture or technique. Among these may be mentioned specially four papers dealing with the measurement of photographic density. This has never yet been standardized and, though for most technical purposes 'density' is sufficiently well understood to permit useful application of measurement to laboratory testing and works control, yet for precise comparison of results obtained on different instruments of slightly different design, there is need for much further progress. Perhaps the new information may be useful in achieving this. There are, however, several papers which are devoted to subjects which are outside the photographic field altogether, and here we may cite a group of papers by Dr. K. C. D. Hickman and colleagues dealing with fractional distillation of phlegmatic liquids. The work has resulted in development of much improved apparatus for distillation of vitamins. As with previous volumes, each paper is presented without drastic shortening, so that to those who are not able to turn to the full papers in their original journals the volume is of exceptional value.

\section{Scottish Wild-Life Preservation}

The Council of the Zoological Society of Scotland recently set up a Scottish Nature Reserve Committee, on which various public bodies are represented, for the purpose of promoting the preservation of Scottish wild-life. The Committee wishes to obtain full and accurate information regarding the existence, numbers, increase or decrease, and generally the most complete statistics, of native species in different parts of the country. The Committee believes that helpful information of this kind could be furnished by local natural history societies and other associations as well as by landowners, gamekeepers and others, and, therefore, it desires the co-operation of anyone who could furnish such information and who would collaborate with the Committee in the work which it hopes to do. Another aspect of the work which the Committee might usefully undertake would be the mapping out of areas in Scotland which might be suitable for Nature reserves or sanctuaries. Anyone who possesses local knowledge of the suitability of land for such a purpose could greatly assist the Committee by communicating such information to it. Communications should be sent to the DirectorSecretary, the Zoological Society of Scotland, Zoological Park, Edinburgh, 12.

\section{Biology and Social Studies}

Fact, now successfully at the end of two years' activity, which produces, in its own phrase, "A monograph a month", has just brought out another scientific number bearing the title "Biology and Man : Past and Future" by Prof. Marcel Prenant of the Sorbonne. This for the most part consists of an interesting and well-written summary of the main trends in the history of biology in relation to 